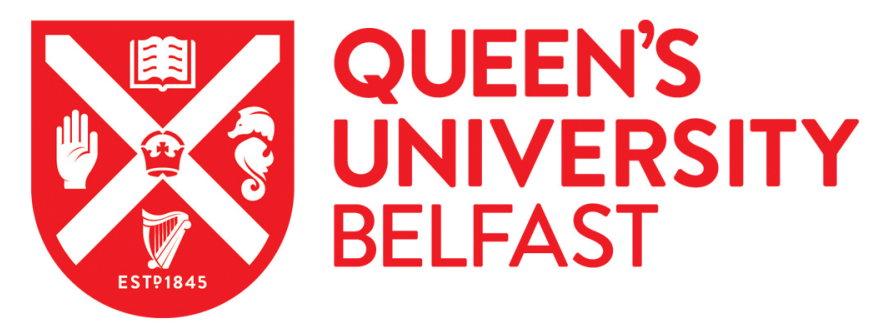

\title{
Exploring young people's understanding of culture: a study from Northern Ireland
}

Durrer, V., Kelly, G., McKnight, M., \& Schubotz, D. (2020). Exploring young people's understanding of culture: a study from Northern Ireland. Cultural Trends, 29(1), 4-18. https://doi.org/10.1080/09548963.2019.1692184

\section{Published in:}

Cultural Trends

\section{Document Version:}

Peer reviewed version

Queen's University Belfast - Research Portal:

Link to publication record in Queen's University Belfast Research Portal

Publisher rights

(c) 2018 Informa UK Limited, trading as Taylor \& Francis Group.

This work is made available online in accordance with the publisher's policies. Please refer to any applicable terms of use of the publisher.

\section{General rights}

Copyright for the publications made accessible via the Queen's University Belfast Research Portal is retained by the author(s) and / or other copyright owners and it is a condition of accessing these publications that users recognise and abide by the legal requirements associated with these rights.

Take down policy

The Research Portal is Queen's institutional repository that provides access to Queen's research output. Every effort has been made to ensure that content in the Research Portal does not infringe any person's rights, or applicable UK laws. If you discover content in the Research Portal that you believe breaches copyright or violates any law, please contact openaccess@qub.ac.uk. 


\title{
Exploring young people's understanding of culture: A Study from Northern Ireland
}

\author{
Victoria Durrer \\ School of Arts, English and Languages, Queen's University, Belfast, Northern Ireland
}

Grace Kelly

School of Social Sciences, Education and Social Work, Queen's University, Belfast, Northern Ireland

\section{Martina McKnight}

School of Social Sciences, Education and Social Work, Queen's University, Belfast, Northern Ireland

\section{Dirk Schubotz}

School of Social Sciences, Education and Social Work, Queen's University, Belfast, Northern Ireland

Corresponding Author: Victoria Durrer, School of Arts, English and Languages, Queen's University, Belfast, Northern Ireland, BT7 1NN, Northern Ireland, v.durrer@qub.ac.uk

Victoria Durrer is Lecturer in Arts Management and Cultural Policy at Queens University Belfast. She is co-founder of the Cultural Policy Observatory Ireland and the AHRC funded research network, Brokering Intercultural Exchange and Co-Investigator of the AHRC funded project The Art of Reconciliation. She serves on the editorial team of the Irish Journal of Arts Management and Cultural Policy.

Martina McKnight is a Research Fellow with ARK. Her research interests include gender, young people, conflict and transition in Northern Ireland and qualitative methods.

Grace Kelly is a Research Fellow with the School of Social Sciences, Education and Social Work at Queen's University Belfast. Her main area of work is social policy, with particular research interests in deprivation, poverty, social exclusion and equality.

Dirk Schubotz studied Social Sciences in Berlin and Belfast and obtained his Dr phil. from Kassel University. He worked as a Research Fellow at Ulster University (UU) and Queen's University Belfast (QUB) before becoming a Lecturer in Social Policy at QUB in 2012. Dirk has directed ARK's Young Life and Times (YLT) survey since 2003. Dirk's research interests include children and young people, (participatory) research methods, sexuality and sexual health, identity, education and community relations. 


\title{
Exploring young people's understanding of culture: A Study from Northern Ireland
}

\begin{abstract}
This article highlights the need for greater understanding of the role that historical and socio-cultural and political context may play in shaping perceptions of culture and cultural value (Kasynska, 2015). Findings draw on the 2016 Young Life and Times (YLT) survey, an annual attitudinal survey of 16-year olds in Northern Ireland, and four follow-up focus group discussions. The results complement existing research on cultural participation, which relates forms of engagement with factors, such as, age, location of residence, gender, and income (Bennett et al., 2009; Manchester \& Pett, 2015; van Wel, et al., 2006). However, reflecting, to some degree, the specificities of the study's location in Northern Ireland, we also found that cultural participation and understandings of what counts as culture have strong connections to history, place, religion, tradition and family. Furthermore, while our research participants placed a high level of personal importance on the informal activities in which they engage on a daily basis, it was those activities associated with tradition and family, which they perceived as having higher cultural importance.
\end{abstract}

Key Words: cultural participation, cultural value, young people, Northern Ireland

\section{Introduction}

Young people's cultural participation is a priority in Northern Irish public policy, not just as a means to facilitate or support engagement in publicly-subsidised arts, but also regarding ‘parity of esteem' for cultures and cultural identities -(ACNI, 2013; DE, 2016; NIE, 2016; OFMDFM, 2013). While-Yet, while NI state-based research reports (DfC, 2017) have made an effort to better understand young people's engagement and viewpoints regarding culture, 


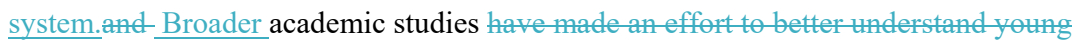
people's engagement and viewpoints regarding culture, many tend to focus on the role of cultural participation and consumption practices in young people's social, personal and educational development (van Hek \& Kraaykamp, 2015). While important, these studies often aim to build a case for state support for particular forms of cultural engagement. However, very little attention has been given to the meanings and values young people themselves attach to cultural activities (Gibson \& Edwards, 2016; Manchester \& Pett, 2015). This omission is particularly perplexing in a Northern Irish context where, twenty years after the cessation of sustained violence, contested notions of culture and how culture should be expressed or valued remain important, not only, politically and economically but in everyday life.

This article presents findings from a pilot study exploring how young people in Northern Ireland interpret culture and participate in cultural activities. The study aimed to foreground these young people's perspectives and experiences within the growing body of academic research in UK and European cultural policy studies, which critiques how cultural participation is narrowly understood and valued in government arts and cultural policies (Gilmore, 2013; Kaszynska, 2015; Miles \& Gibson, 2016; Stevenson, Balling, \& KannRasmussen, 2017). Such work calls for greater acknowledgement of subjective, everyday and localised cultural practices for understanding the importance individuals and communities attach to different forms of cultural activities and participation.

Findings presented draw on the 2016 Young Life and Times (YLT) survey, an annual attitudinal survey of 16-year olds, and four follow-up focus group discussions held across Northern Ireland. The data gathered contributes to understandings of young people's 
everyday cultural engagement, especially in relation to the values they place on different types of cultural activities. Our findings support -existing research which shows that young people typically engage in informal cultural activities, such as shopping, gathering with friends or going online, as well as art making and attending arts activities (Manchester \& Pett, 2015; van Wel, Couwenbergh-Soeterboek, Couwenbergh, Ter Bogt, \& Raaijmakers, 2006); and that factors, such as, age, location, gender and income are related to types and forms of participation (Bennett, Savage, Silva, Warde, Gayo-Cal, \& Wright., 2009).

Reflecting, to some degree, the specificities of the study's location, we also found that for many participants, cultural participation and understandings of what counts as culture have strong connections to history, place, religion, tradition and family and vary along the demographic lines outlined above. Furthermore, while our research participants placed a high level of personal importance on the informal activities in which they engage on a daily basis, it was those activities associated with tradition, religion and family, which they perceived as having higher cultural importance.

As a result, exploring and questioning policy-based assumptions about what constitutes 'culture' and who makes that decision is particularly, and perhaps not surprisingly, fraught in a Northern Irish context. Still, the study brings further to the fore the importance of approaching cultural policymaking as more than a concern regarding the development, $\underline{\text { market-failure and / or maintenance of arts, heritage and cultural industries, and, one that }}$ considers cultural policymaking as a cross-cutting policy question regarding what and whose cultural values are included and excluded, by what means and to what end (O'Brien and Oakeley, 2017) as well as how this relates to geographical place, tradition, religion and identity (Finlayson, 1997, p. 79). At the heart of these issues are not only the "way that culture is produced [and consumed] and [the] relationship [of both] to politics" (Finlayson, 
1997, p. 79), but what value governments and its people place on both as well as how those values are discovered and heard, methodologically.

The article opens with a brief contextual discussion of the relationship of symbols and practices to understandings of culture and cultural participation in Northern Ireland. This is followed by a description of the public policy context in Northern Ireland and a review of relevant literature from youth, sociology, cultural policy and Irish studies from which our research questions originated. Following an explication of our methodology, we present an analysis of findings, followed by a discussion of the implications of these for cultural policymaking.

\section{Cultural symbols and practices in Northern Ireland}

The reasons for Northern Ireland's troubled history and the most recent and protracted period of violence, the 'Troubles', which lasted thirty years and claimed over 3700 lives, are multiple and contested and beyond the scope of this paper (see Hayes \& McAllister 2013; McDowell 2007; Tonge 2002). While much progress has been made in Northern Ireland since 1998, not least of which is the absence of sustained violence, ethno-religious segregation in housing and education continue, paramilitary violence remains problematic in some communities and commemorations of particular historical and/or cultural events still create tensions and lead to street disorder and inter community conflict. Currently, a lack of agreement between the two main political parties, (the Democratic Unionist Party (DUP) and Sinn Féin), one element of which relates to understandings of and respect for culture, language in particular, has resulted in political stalemate. 
As such, while the young people responding to the YLT survey have grown up in this period of relative peace and stability, the legacies of 'the Troubles' and a variety of everyday practices, cultural allegiances and symbols continue to impact on their attitudes and perceptions. Moreover, 'culture' can be invoked and symbolically displayed to signify both division and unity, and, as Wilson (2016, p. 123) points out, young people in Northern Ireland are living in a context where a lessening of the former violence of 'the Troubles' has resulted in heightened clashes over cultural symbols (Wilson, 2016, p.-123 - 124).

"[These] culture wars are fought out in physical space: parading on highways, erecting flags in neighbourhoods, [and] painting murals in estates [with initiatives and calls to develop] neutral, shared and cosmopolitan spaces."1

This continued importance of the relationship of the symbolic, notions of belonging, identity and the everyday is not limited to Northern Ireland. Reflecting the work of Stuart Hall (1997), Singh's (2014) study of the cultural value of South Asian arts shows how arts and cultural activities like music, sports, and dance as well as more traditional rituals, performances and creative expressions associated with ethno-national and / or religious identity, for instance, can signify, communicate and foster a sense of collective belonging in ways that positively acknowledge and affirm the identities of minority cultural groups amongst the wider British public. However, such expressions can equally foster "separation" in post-conflict societies (Crossick \& Kasyznska, 2016, p. 154). Moreover, symbolic materials and practices are critical aspects of the "everyday experiences and life histories" that not only influence young people's attitudes and values towards culture (Manchester \& Pett, 2015, p. 227), but also the ways in which they "construct... a narrative of self-identity" (Thompson, 1995, p. 210 quoted in Abbott-Chapman \& Roberston, 2001, p. 486). How this 
takes place is dependent upon the "material conditions of [individuals'] lives, their expectations and their evaluations of experiences, as well as their aspirations and ideals" (Abbott-Chapman \& Roberston, 2001, p. 486). Furthermore, the activities young people perceive to be of cultural value are undoubtedly influenced by a "situated...and internal [social] and [place-based] logic" (Gilmore, 2013, p. 86). So, understanding the specificities of how notions of culture play out in Northern Ireland can contribute positively to these broader debates.

\section{Northern Ireland's Policy Context}

Northern Irish public policy reflects this cultural complexity. The presence of flags and murals in communities are key cultural symbols indicated in executive level policies as matters for consideration in "resolving the challenging legacy of [the] past" (OFMDFM, 2013, p. 22). Children and young people are a key focus of broader government work in areas of cultural expression (NIE, 2016; OFMDFM, 2013). Within Together Building a United Community (TBUC), improving the "attitudes of young people" and fostering their "active role in building good relations" are a primary focus in promoting open, accessible, safe and "united" communities "where cultural expression is celebrated and embraced" (OFMDFM, 2013 , p. 3). Arts and sports activities are referred to as tools for fostering good relations, reconciliation and the exploration of cultures and cultural identities, with particular mention of work through the Arts Council Northern Ireland, district Councils and the Community Relations Council.

While government and quasi-state bodies have sought to capture young people's behaviours and attitudes regarding cultural activity, much is focused on legitimised and state-funded 
forms of art and culture, including sport, at the exclusion of others (DfC, 2017). For instance, the youth-friendly version of the consultation document for Northern Ireland's first Strategy for Culture Arts and Leisure ${ }^{2}$, which was produced by the then Department of Culture, Arts and Leisure (DCAL) in 2015, illustrates this point. The document asked young people to respond to the question, "What does arts and culture mean to you?", but framed this by the following statement:

“.... it means lots of different things to lots of different people but it can include things like... books, plays, television, music, museums, comedy, opera, orchestra, dance, circus, concerts, art galleries, music gigs, movies, festivals" (DCAL, 2015, p. 2)

Thus, what is presented in this list becomes imbued with value. Conspicuous by their absence are digital activities like video gaming or engagement on social media, all critical to understanding young people's cultural engagement (Durrer, 2011). In addition, parades, wall murals, and marching bands, which not only have strong association with traditional, or ethno-national and religious identities, but also a significant presence in the everyday lives of communities in Northern Ireland are also absent (McKnight \& Schubotz, 2017).

\section{Broadening perspectives on youth cultural participation}

The approach taken in Northern Ireland reflects trends in the UK, whereby young people's cultural participation is narrowly considered in terms of the economic and social benefits gained through state-funded art projects, with cultural activity being an act of consumption that generates a return on financial investment. A number of academic studies have, however, brought to light different issues in patterns and behaviours. These include studies of participation in a variety of art forms by young people across ethnic backgrounds (Wel et al., 
2005), the importance of familial and educational influences on cultural taste (Nagel, 2010; van Hek \& Kraaykamp 2015; Willekens \& Lievens, 2014; Yaish \& Katz-Gerro, 2012) and issues of identity (Miles, 2000). Such studies often consider cultural participation in relation to issues of social integration and secial-horizontal, rather than vertical stratification.

Research has also considered young people's engagement with specific art forms, sport and cultural institutions and bodies (Durrer, 2011; Horlock, 2000; Selwood, 1997; Wheeler, 2012) and the social, cognitive and personal development of such engagement (ACNI, 2013; Crossick \& Kaszynska, 2016). Young people's engagement with culture can also be seen in leisure habits (Abbott-Chapman \& Robertson, 2001; Leverson et al., 2012; Miles et al., 1997) as well as digital and media literacy and its place in young people's everyday life and learning (Buckingham, 2004; Livingstone \& Sefton-Green, 2016).

Research within cultural sociology and cultural policy studies presents a more nuanced and contextualised view of how culture may be understood to include the everyday (see Gilmore, 2016; Manchester \& Pett, 2015; Miles \& Gibson, 2016). This work, reveals how locally situated practices and ordinary relationships, such as local networks, family and community ties, in addition to publicly funded cultural institutions, are significant factors in how individuals establish value and attach meaning to culture.

Of particular relevance is a recent study by Manchester and Pett (2015), which argues for the importance of youth voice (see also Gibson and Edwards, 2016). In terms of cultural engagement as a practice of consumption, their analysis highlights the role of "everyday experiences and life histories" not only in shaping the activities in which young people take part but also in how they perceive and value them (Manchester \& Pett, 2015 p. 227). Their 
study highlights the importance of place and locality, particularly in terms of socio-economic advantage, in influencing "how culture is experienced and valued", and the role each play in perceptions and understandings of culture and engagement in cultural activities as an expression of identity. The ways in which the study brings "social and spatial dimensions" (p.226) to bear in considering young people's relationship to cultural activity resonates with our findings.

\section{Methodology}

To uncover the types of cultural activity young people engage in every day and to understand the meaning, attitudes and values they attach to these-whether that be in what they personally take part or of what they are aware of $\longrightarrow$ - we employed an explorative mixed methods approach, consisting of a module in the 2016 YLT survey and follow-up focus groups. The annual YLT survey, which has been running in its current format since 2003, is a randomised postal attitude survey that records the views of 16-year olds in Northern Ireland on a range of issues, such as, community relations, health and education. The sample for the survey is drawn from the Child Benefit Register held by HMRC who administer the benefit. While primarily a postal survey it may be completed online, and in 2016, 1,009 16-year olds participated.

The 2016 YLT survey included a series of open and closed questions on culture, beginning with an open-ended question that asked participants what sort of activities they associated with the word 'culture'. Respondents were then given a list of cultural activities and asked to select those that described how they expressed their culture; subsequent questions addressed the types of activities they were involved in, barriers to participation and whether they 
attended a youth project or club. At the end of the questionnaire respondents were asked if they would like to participate in follow-up focus group discussions.

After some initial analysis, four focus groups with 30 participants in total were held in different locations in Northern Ireland in March 2017. The venues were chosen to ensure a geographic spread as well as a mixture of urban, small town and rural background. All focus group participants received a $£ 20$ gift voucher. Group discussions were facilitated by two or three members of the research team; signed consent was obtained from each participant before the group discussion began, and participants were made aware that they could withdraw at any time without giving a reason. Prior to the discussions, participants were sent a short diary and asked to note what they did in their spare time over the course of a week.

-Participants' views were sought on attitudes to and understandings of culture and cultural activity on the basis of general discussion and more structured tasks and activities. Ideas explored included what associations they make with different types of cultural activity; how they feel culture is typically expressed; what might influence decisions on participation and the type of spaces and places which might facilitate or hinder young people's participation in cultural activity.

\section{Survey participation served as a recruitment tool for the focus groups. While time and}

\section{funding constraints did not allow the development of research tools with participants, we}

drew onUsing a participant-led, interactive and age-appropriate adaptation of Stephenson's Q Methodology (1953) for qualitative research (Brown, 1996), eaEach group of participants was split into two smaller groups and given a set of cards containing a word or statement relating to cultural activities. To honour youth voice, $\mathrm{t}$ These texts were derived mainly from

Formatted: Font: (Default) Times New Roman Formatted: Comment Text, Left Formatted: Font: (Default) Times New Roman Formatted: Font: (Default) Times New Roman Formatted: Font: (Default) Times New Roman 
the open-ended responses to the YLT survey question: 'When you hear the word 'culture' what sort of activities does this make you think of?'. To further provide space for the inclusion of new topics by participants, eEach set of cards also contained five blank cards to be completed if participants thought an important cultural activity missing, and there were more cards than spaces on the grid. Each group was asked to collectively rank each card onto a grid to reflect its importance as a cultural activity, the most important representation being placed on the ' +4 ' column, with the next two most important being placed in the ' +3 ' column and so on (see Figure 2, p.19 below). At the end of the exercise a nominated spokesperson shared feedback to the group.

\section{Findings}

16-year olds' associations with, and expressions of, culture

The responses to the YLT open question 'What sort of activities do you think of when you hear the word culture?' were wide-ranging, including music, the most frequently mentioned, as well as sport, dance, and other art forms; but also religious practices, heritage, food, clothes and styles of dress, customs, language, and traditions-both familial and societal. However, the proportion of 16-year olds who stated they expressed their own culture in some of these ways was relatively modest (Table 1); religious beliefs and practice (58\%), and language spoken (57\%) were the two main ways in which YLT participants felt they expressed their culture. Just half (51\%) felt they expressed their culture in the activities they took part in, and only $44 \%$ felt they expressed their culture through the music they listened to, which, as previously mentioned, was the activity most often stated in response to the initial open question.

\section{[Insert Table 1 here]}


The importance that participants placed on these activities as expressions of their culture varied significantly by some of the background variables recorded. For example, 58 percent of 16-year olds, who self-identified as being from financially 'well-off' backgrounds, felt they expressed their culture via the activities they took part in compared to 52 percent of those who self-identified as being from 'average well-off' backgrounds, and just 39 percent of those self-identifying as from 'not-well off' backgrounds. This difference is statistically highly significant $(\mathrm{p}<0.000)$.

As could be expected, religious beliefs and practices were much more important as expressions of culture for young people who said they belonged to a religion (72\%) than those who did not $(24 \%)$. However, religious beliefs and practices were also much more important as expressions of culture to respondents who identified as being from 'well-off' backgrounds (62\%) than those who perceived themselves as 'not well-off' (41\%); by respondents who lived in rural settings (68\%) than those in urban areas $(51 \%)$ or small towns (52\%) and by those identifying as Irish (71\%) compared to those identifying as British (56\%) or Northern Irish (49\%). All of these differences were statistically highly significant $(\mathrm{p}<0.000)$.

We found no statistical evidence for a link between religious or national identity and language or music as expressions of culture. Where Catholics and those identifying with Irish national identify did feel a much stronger association with culture than those identifying as British or Northern Irish, was in the activities they took part in $(62 \%$ and $46 \%$ respectively, $\mathrm{p}<0.000$ ), religious beliefs and practices (Irish: $71 \%$, British: $56 \%$, Northern Irish: $49 \%$, 
$\mathrm{p}<0.000$ ) and also the clothes they wore (Irish: 45\%, British 37\%, Northern Irish 35\%, $\mathrm{p}=0.023)$.

The largest differences overall in expressions of culture were found between those 16-year olds in rural settings and those from more urban areas. In addition to the already reported strong association with religious practices and beliefs as cultural expression, young people from rural areas were also much more likely $(\mathrm{p}<0.000)$ to regard the activities they took part in as cultural expressions (58\%) than their counterparts from urban areas $(50 \%)$ and small towns (45\%); however, they were much less likely to associate music they listened to or films they watched with expressions of culture than young people who lived in small towns or in urban settings $(38 \%, 46 \%$ and $53 \%$ respectively, $\mathrm{p}<0.000)$. With regard to actual participation in cultural activities, those from rural areas were least likely to participate in all activities accept for attending a sporting event, as Figure 1 shows. The differences were statistically significant for watching TV/videos/DVDs; listening to music; going to the movies; attending cultural or sporting events; playing online games; and making art.

[Insert Figure 1 here] Figure 1: Frequency with which respondents undertake cultural activities. By type of place where they live (mean).*

Overall, our survey data supports existing research, which highlights the relationship between the activities in which one participates and class and gender as well as educational, socioeconomic and place-based circumstances (Bennett, et al., 2009; DfC, 2016; McCallion 2015; Tyrell and Harmer, 2015). For instance, we found that males were more likely than females to associate activities they took part in $(55 \%$ and $48 \%)$ with expressions of culture, but less likely than females to do so when it comes to music and films (38\% and $49 \%$ ), religious 
practice $(55 \%$ and $61 \%)$, language (53\% and $60 \%)$ and food $(35 \%$ and $47 \%)$. We also found that 16-year olds attending Grammar schools were statistically much more likely to read books and to attend concerts, theatre, dance, music sessions and exhibitions than 16-year olds at non-Grammar schools.

In terms of barriers to more cultural participation, costs, someone to go with, and lack of suitable activities were much more frequently cited by participants from 'not well-off' backgrounds, whereas lack of time was significantly more likely to be mentioned by 'welloff' respondents. Lack of transport or difficulties accessing transport was more of an issue for young people in rural areas (43\%) than those in urban areas or small towns $(35 \%)$. On the other hand, young people in the city were much more likely to have safety concerns $(10 \%)$, than their counterparts from small towns (7\%) and in rural areas (3\%). Respondents from different locations did not differ statistically in how likely they were to say that lack of time prevented them from taking part in more cultural events.

Perhaps, unsurprisingly, given the complexities underpinning understandings of culture, the focus group findings present more nuanced interpretations and complex reflections on how participants perceive, experience and engage with 'culture'. While the focus group responses were similar to those gathered in the survey in terms of the activities they connected to 'culture', what emerged strongly was how culture was linked to tradition and family:

Tradition. Doing what you're used to doing with your family and stuff.

(Female, Group B)

It's family. What your family's culture is, is going to be your culture isn't it? You can't really break away from it. It's what you were born into. You don't 
become part of a culture, you never hear of that happening. Whatever you're born into is your culture. (Female, Group E)

While the second participant draws attention to the notion of culture as immutable, tied strongly to family and tradition, other young people understood culture as more fluid and evolving, open to external influences and, to a degree, self-fashioning. They drew attention to how culture, collective and individual, could change as people became exposed to a range of different experiences and influences, for example, heritage, cuisine, or the arts, and to the links between culture and identity:

\footnotetext{
I think here, Northern Ireland, Ulster, there's so many different cultures coming together. Celtic heritage, Scottish heritage, French heritage, it's all kind of bundled together to create this new culture that you can see where it stems from through music and dance and the way you talk and interact. (Female, Group E)
}

Your culture is what you decide. If I decided to stay within the Indian culture, I could. But I just don't chose to. Some of my culture is Indian, Irish, British. You decide basically. (Male, Group E)

When discussing what came to mind when they heard the term 'cultural activity', common examples were the parades that occur periodically across Northern Ireland to commemorate specific historical events or figures, and special occasions such as family weddings or religious celebrations. However, for some of the young people cultural activities did not have any local associations but were connected to religious festivals from other countries, for example, Ramadan and Shinto. Their initial responses, therefore, to understandings of what 
constituted a cultural activity focused, to a degree, on the extraordinary rather than the everyday.

However, in discussing their daily diaries other 'more everyday' activities emerged: hanging out with friends, reading books, playing in bands, internet based activities, going to the theatre, participating in an amateur drama group. Common to all participants during the school week were school work (studying/revising/coursework/homework), part-time work, watching TV/Netflix, listening to music, music lessons, shopping, talking to friends, playing video games, going to the cinema, spending time with family, walking the dog, keeping fit/working out. Weekend activities generally involved more schoolwork and spending time with family and friends (e.g. meals out, going to a friend's house) and, for many, attending church. In discussing these activities participants differentiated between those that were 'fun, everyday stuff', for example, playing video games, listening to music, and more 'important' activities, which could also be fun, such as, homework and spending time with family and friends.

When asked if these everyday activities were 'cultural' activities, participants' initial response was "no", with the exception of attending church which was regarded, to quote one participant, as "obviously" cultural given its connection to family and tradition. It was evident that defining what could count as 'culture' or a 'cultural activity' was problematic for our participants. In probing for greater clarification, what began to emerge were the nuanced distinctions that these young people made in assessing cultural value.

The extent to which distinctions were made was quite striking in their complexity, as exemplified when a young woman (Group D) was discussing her diary entries. She initially 
defined nothing she had recorded as cultural, albeit that the activities, such as going to Girl Guides and going with her family to watch her sister perform in a local drama group, were important to her. It subsequently emerged that she too had been part of this drama group but had to withdraw due to school demands. Our assumption was that this participant would view her membership of the drama group as a cultural activity. However, when probed she explained that what made it a cultural activity was its connection to the church, particularly evidenced in the way each session began with prayers. She indicated that without the prayers she would not think of the drama group as a cultural activity. She further expressed how important Girl Guiding was to her, but confirmed it was not a cultural activity. Her rationale for not counting Girl Guides as 'cultural' was that the commonly shared association of Girl Guides with the Protestant culture in Northern Ireland did not sit with her own identification as a Catholic.

Further complexity in perceptions of the personal and cultural importance of activities was revealed during engagement with the Q Sort activity. When asking participants to rank activities in order of 'importance as a cultural activity' we purposefully left the issue of importance open to interpretation. As evidenced in Figure 2 below, with few exceptions, high importance was attributed to activities with a strong connection to family, tradition, heritage and community. Other activities considered to be culturally important were 'learning a different language' and 'learning about different people's lives'. Ranked as least important were those activities typically associated with leisure and the arts.

\section{Figure 2: Q sort grid Group C}

(insert Figure 2 here) 
In rationalising their ordering of activities it became clear that decisions were not based on how important an activity was to participants in their everyday lives. Rather, decisions were largely based on the extent to which history, family, tradition and religion were regarded as important elements in the activity. As such, when participants were asked whether their grid would have looked differently if they had been asked to rank the activities in order of how important each activity was to them personally rather than how important each was in terms of being a 'cultural activity' most participants explained that the ranking would reverse, with celebrating a local / community festival and practicing faith becoming the least important and activities like going to the cinema or going online gaining in importance.

\section{Conclusion}

The findings presented reveal a sample of young people's orientations and values regarding cultural participation and what they define as cultural activity. Young people take part in a variety of cultural activities. While including art, shopping, gathering with friends or going online, cultural participation for these young people also had a strong connection to ethnonational identity, tradition, religious and family customs. While our findings support existing research on young people's engagement in cultural activities, and the influence of personal and socio-geographic and economic circumstances (Bennett et al., 2009; Manchester \& Pett, 2015; van Wel, et al., 2006), they develop understandings of young people's everyday cultural engagement, particularly regarding the values young people perceive to be placed on different types of cultural activities. 
There is a strong contextual component to the study. In its focus on Northern Ireland, the research highlights the need for further consideration of "situated cultural practices ${ }_{2} \ldots$ internal logics, histories and structures" in understanding and establishing cultural meaning, attitudes and value (Gilmore, 2013, p. 86; Miles \& Sullivan, 2012; Manchester \& Pett, 2015). The findings reveal that the activities in which young people engage during their spare time are commonly perceived by them to be part of everyday life, yet they are not what they perceive to be of cultural value unless, generally, they are attached to heritage, tradition, family, religion, and/or local identity. As a result, the meanings, attitudes and values that these young people attach to cultural activities are, to a degree, reflective of the history and the contested nature of culture in Northern Ireland. Yet, despite the priority on children and young people's behaviours and attitudes towards culture in Northern Irish public policy, there is a continued emphasis on young people's cultural engagement in publicly funded art forms, with particular attention to issues of market failure in relation to the publicly subsidised, professional arts. Such a limited focus risks neglecting the varied ways in which young people experience, define and value 'culture' and further underlines a policy neglect concerning the ways in which the concept of culture may play out in both positive and negative ways in the lives of young people in the particular geographical and socio-historical, political context of Northern Ireland.

The history and contested nature of 'culture' in Northern Ireland is a significant factor in how young people perceive cultural value and, as such, how they value or define artistic and cultural activities. These findings add to understandings of young people's relationships to cultural participation beyond the narrow confines of a stratified consumption practice, further highlighting the complexities involved in interpreting and experiencing culture, particularly 
in relation to age. As a preliminary study, it highlights the need for more research on the role that place, but particularly historical and socio-cultural and political context, have on perceptions of cultural value. The research thus has implications for how we might think not only about cultural value (Crossick \& Kaszynska, 2016), but also cultural policymaking for and with young people and communities.

Finally, the study raises issues regarding how policymakers might engage with young people in understanding their attitudes and behaviours towards cultural activity. The methods employed and the questions asked about culture, not only place valuations on certain forms of activity in and of themselves, but they also may influence the valuations placed on them by research participants (Arskey and Knight, 1999, p. 10). Critical, is what questions are asked, by whom and in what way. While limited within its scope, the approach outlined here when brought together with other studies on young people and cultural participation (Manchester and Pett, 2015), show the potential of integrating both creative and social scientific methods

of participatory engagement in data collection for providing greater voice and perhaps

leadership in cultural policymaking by young people.

\section{Funding}

The Young Life and Times (YLT) survey is part-funded by: NI Executive Office, the Department of Education, the EU Programme for Peace and Reconciliation in Northern Ireland and the Border Regions of Ireland, the Community Relations Council, the Carnegie Young People Trust, and Sport NI. The Centre for Evidence and Social Innovation, Queen's University Belfast provided funding for the cultural component of the survey and focus groups.

\section{References}

Abbott-Chapman, J., \& Robertson, M. (2001). Youth, leisure and home: Space, place and identity. Loisir et société/Society and Leisure, 24(2), 485-506.

Arskey, H. and Knight, P. (1999). Interviewing for Social Scientists: An Introductory 


\section{Resource with Examples. London: Sage Publications,}

Arts Council Northern Ireland (ACNI) (2013). Youth arts strategy 2013 - 2017. Belfast: Arts Council Northern Ireland.

Bennett, T., Savage, M., Silva, E. B., Warde, A., Gayo-Cal, M., \& Wright, D. (2009). Culture, class, distinction. London: Routledge.

Brown, S.R. (1996) Q Methodology and qualitative research, Qualitative Health Research, November, (4), pp 561-567.

Buckingham, D. (2004). The media literacy of children and young people: A review of the research literature on behalf of Ofcom. London: Centre for the Study of Children Youth and Media Institute of Education, University of London.s.

Crossick, G., \& Kaszynska, P. (2014). Under construction: Towards a framework for cultural value. Cultural Trends, 23(2), 120-131

Crossick, G., \& Kaszynska, P. (2016). Understanding the value of arts and culture, The AHRC cultural value project. Swindon: Arts and Humanities Research Council.s is: Retrieved from: http://www.ahrc.ac.uk/documents/publications/cultural-value-project-final-report/

Department of Culture, Arts and Leisure (DCAL). (2015). Making culture and arts available to everyone, our ten year plan, youth friendly version. Belfast: Stationary Office.

DE (Department of Education). (2016). Department of Education, Children and young people's strategy 2017 - 2027. Belfast: Stationary Office.

DfC (2017) Engagement in culture, arts and leisure by young people in Northern Ireland. Belfast: Stationary Office. Retrieved from: https://www.gov.uk/government/statistics/engagement-in-culture-arts-and-leisure-by-youngpeople-in-northern-ireland-2016

Durrer, V. (2011). Rethinking Local Government Support for Youth Arts: The Case of NOISE South Dublin, The Journal of Arts Management, Law, and Society, 41(1), 55-75, DOI: $10.1080 / 10632921.2011 .545717$

\section{Finlayson, A. (1997). The problem of 'culture' in Northern Ireland: a critique of the Cultural Traditions Group. The Irish Review, 20, 76-88.}

Gibson, L. \& Edwards, D. (2016). Facilitated participation: cultural value, risk and the agency of young people in care, Cultural Trends, 25(3), 194-204, DOI: $10.1080 / 09548963.2016 .1204049$

Gilmore, A. (2013). Cold sports, Crap towns. Cultural Trends, 22(2), 8 - 96. 
Graham, B., \& Nash, C. (2006). A shared future: territoriality, pluralism and public policy in Northern Ireland. Political Geography, 25(3), 253-278.

Hall, S. (1997). Representation: cultural representations and signifying practices. Thousand Oaks, California: Sage in association with the Open University.

Hayes, B., \& McAlister, I. (2013). Conflict to peace. Politics and society in Northern Ireland over half a century. Manchester: Manchester University Press.

Horlock, N. (ed.) (2000). Testing the Water: Young People and Galleries, Liverpool: Liverpool University Press.

Kaszynska, P. (2015). Capturing the vanishing point: Subjective experiences and cultural value. Cultural Trends, 24(3), 256-266, DOI: 10.1080/09548963.2015.1066077

Leversen, I., Danielsen, A. G., Birkeland, M. S., \& Samdal, O. (2012). Basic psychological need satisfaction in leisure activities and adolescents' life satisfaction. Journal of Youth and Adolescence, 41(12), 1588-1599.

Livingstone, S., \& Sefton-Green, J. (2016). The class: Living and learning in the digital age. New York: NYU Press.

Manchester, H. \& Pett, E. (2015). Teenage kicks: Exploring cultural value from a youth perspective, Cultural Trends, 24(3), 223-231, DOI: 10.1080/09548963.2015.1066078

McCallion, C. (2015). Engagement in culture, arts and leisure by young people in NI: Headline findings from the young persons' behaviour and attitudes survey, 2013, DCAL Findings 2014/15. Belfast DCAL.

McDowell, S. (2007). Who are the victims? Debates, concepts and contestation in 'postconflict' Northern Ireland. Derry/Londonderry: CAIN. Retrieved from:

http://cain.ulst.ac.uk/victims/introduction/smcd07whoarethevictims.html

McKnight, M. \& Schubotz, D. (2017). Shared future - shared values? Taking stock of the peace process in Northern Ireland: teenagers' perspectives._Cultural Trends, 26(3), 216-232, DOI: 10.1080/09548963.2017.1342995

Miles, A. \& Gibson, L. (2016). Everyday participation and cultural value. Cultural Trends, 25(3), 151-157, DOI: 10.1080/09548963.2016.1204043

Miles, A. \& Sullivan, A. (2012). Understanding participation in culture and sport: Mixing methods, reordering knowledges. Cultural Trends, 21(4), 311-324, DOI:

$10.1080 / 09548963.2012 .726795$ 
Miles, S. (2000). Youth lifestyles in a changing world. Ballmore: Open University Press.

Nagel, I. (2010). Cultural participation between the ages of 14 and 24: intergenerational transmission or cultural mobility? European Sociological Review, 26(5) 541-556.

Nic Craith, M. (2003). Culture and identity politics in Northern Ireland. London: Palgrave Macmillan.

NI Stastistics and Research Agency. (NISRA). (2014). Continuous Household Survey 2013/14. Belfast: Central Survey Unit, NISRA.

Northern Ireland Executive (NIE) (2016). Draft Programme for Government Framework, 2016 - 2021. Belfast: NIE.

\section{O'Brien, D. and Oakley, K. (2017). Cultural Policy: Critical Concepts in Media and Cultural * Studies (Introduction). In D. O'Brien and K. Oakley (eds), Cultural Policy: Critical Concepts in Media and Cultural Studies. Abingdon: Routledge, pp. 1-19.}

Office of the First Minister and Deputy First Minster (OFMDFM). (2013). Together: Building a united community (TBUC). Belfast: OFMDFM.

Singh, J. (2014). The cultural value of South Asian arts. London: AHRC. Accessed 29 January 2018 Retrieved from:

https://arts.leeds.ac.uk/jasjitsingh/files/2015/12/JSAHRC_Cultural_Value report.pdf

Stevenson, D., Balling, G., \& Kann-Rasmussen, N. (2017). Cultural participation in Europe: shared problem or shared problematisation?. International Journal of Cultural Policy, 23(1), 89-106.

Thompson, J. (1995). The media and modernity: A social theory of the media. Cambridge: Polity Press.

Tonge, J. (2002). Northern Ireland: Conflict and change. London: Prentice Hall.s[י]

Tyrrell, N., \& Harmer, N. (2015). A good move? Young people's comparisons of rural and urban living in Britain. Childhood, 22(4), 551-565.

van Hek, M., \& Kraaykamp, G. (2015). How do parents affect cultural participation of their children?: Testing hypotheses on the importance of parental example and active parental guidance. Poetics, 52, 124-138. 
Van Wel, F., Couwenbergh-Soeterboek, N., Couwenbergh, C., Ter Bogt, T., \& Raaijmakers, Q. (2006). Ethnicity, youth cultural participation, and cultural reproduction in the Netherlands. Poetics, 34(1), 65-82.

Wheeler, S. (2012). The significance of family culture for sports participation. International review for the sociology of sport, 47(2), 235-252.

Willekens, M., Lievens, J., 2014. Family (and) culture: The effect of cultural capital within the family on the cultural participation of adolescents. Poetics 42, 98-113.

Wilson, R. (2016). Northern Ireland Peace Monitoring Report Number Four. Belfast: Community Relations Council.

Yaish, M., Katz-Gerro, T., 2012. Disentangling 'cultural capital': The consequences of cultural and economic resources for taste and participation. European Sociological Review, 28(2), 169-185.

\footnotetext{
${ }^{1}$ The establishment of a commission on Flags, Identity, Culture and Tradition in 2014 began consultation work in 2016 and is evidence to an acknowledgement on the part of the Northern Irish state that it can not ignore the issue.

${ }^{2}$ Since the completion of the consultation process, the Strategy is currently stalled in government.
} 